\title{
Character Building Through Counseling: The Reducement of Truancy with Cognitive Restructuring Technique
}

\author{
Imroatul Hayyu Erfantinni ${ }^{1}$, Roiyan One Febriani, \\ Dian Eka Aprilia Fitria Ningrum, Vannisa Aviana Melinda \\ Universitas Islam Negeri Maulana Malik Ibrahim, Indonesia \\ Qhayyu.erfantinni@uin-malang.ac.id ${ }^{1}$
}

\begin{abstract}
The purpose of this study is to determine the effectiveness of cognitive restructuring technique to reduce students' truant behavior of Surabaya Pharmacy School. This study used experimental methods with Randomized Pretest-Posttest Control Group Design. The stage of the study was the preparation, the implementation, and the final stage. The subject of study was twelve students of Surabaya Pharmacy School from first, second, and third grades taken at random through the student truancy scale and divided into two groups, control and experiment group. The intervention is done by doing the counseling group with cognitive restructuring technique to reduce the student's truancy behavior. The Data was analyzed using SPSS Paired Sampled T-Test. The analysis result showed that there was a significant difference before and after the intervention using cognitive restructuring in the experiment group. Therefore, the technique of cognitive restructuring is effective to reduce student's truancy at Surabaya Pharmacy School.
\end{abstract}

\section{INTRODUCTION}

Truancy is a critical problem with potentially short and long-lasting negative consequences at both the individual and the societal level. Hence, identifying potential risk and protective factors is a relevant task (Ramberg, Låftman, Fransson, \& Modin, 2019). The purpose of education is basically formed a man into someone who has dignity as well as beneficial to our fellow human beings, given the Caliph in the Earth. The education is done to have a purpose to form personal morals as well as the quality of the character.

Greater demands are increasing, schools must create a learning environment where learners not only feel secure but can also be his own (Sheppard \& Dibbon, 2011). Truancy can be defined as any unexcused or undocumented absence from school taking into account the attendance rules of the specific country (Claes, Hooghe, \& Reeskens, 2009) and can take different forms, ranging from repeated late arrivals to absence from a whole or several school days. Based on the results of the study Morrison (2013) stated if truant behavior is not addressed through a collaborative approach taking numerous risk factors into account, it may have potentially disastrous effects not only for learners but also for their families and communities at large.

Now happening a shift in the meaning of education that leads to the achievement of an academic standard value so that the value of the character has neglected. So many students 
have non-adaptive behavior like unscrupulous truant, a brawl, bullying, smoking, drug use illegal drugs and the other uncommendable deeds. Many violent and moral degradations occurred in Indonesia have affected most of the youth (Agung, 2016). The moral degradation symptoms are indicated by the increase of drug abuse, free sex, crime, violent act, and many other disrespectful behaviors. The source of the multidimensional crisis is the identity crisis and the failure in developing the nation's character education.

Non-adaptive behavior that is often done by the student is truancy. They assumed truancy is familiar so without guilt often truant. When students are truancy then can reflect the personality of the students who are less accountable. This such things gradually undermine the character of the nation. When students don't feel any acceptance and appreciation in school, they tend to look for other environments where they earn satisfy those needs. This often results in absenteeism, truancy and various other forms of disciplinary challenge on learners (Mccray, 2006). There are various types of behavior, the concept of truancy has different meanings for everyone. Truancy can refer to skip certain lessons, absence of psychologically, rejection of the school, and school phobia (Swansea, 2010). But in this article scope limited to truancy the behavior of students who do not attend school to follow a learning activity for reasons that are not exactly even often without reason.

Real data obtained from Surabaya Pharmacy School there are 21\% students of class X ever truancy school, as many as $15 \%$ of the students of Class XI ever truant, and $14 \%$ of students of class XII also truancy in the span of one month. They are truancy because $55 \%$ did not feel able to live the learning activity, $30 \%$ feel bored with the routine as students, and $15 \%$ due to join friends who left the class to look cool. The students of class X have the highest percentage since they are still in a period of adjustment with the teaching and learning activities in pharmaceutical school is much different from subjects in junior high school. Truancy is the beginning of the formation of new behavior problems leads to drop out. In tune with the delivered McKinney (2013) stating that truancy frequently associated with dropping out of school and academic achievement is a bad thing and could increase the likelihood that students will be involved in drug use and alcohol, Brawl, theft, and other more serious delinquency. Not just on students own, negative impacts will continue to spread until the moral damage that is owned by a nation. High rates of crime in this country is the estuary of the behavior of truancy.

In character education then it is very closely related to Islamic norms and ethics. The main sources being the Islamic-based character education guidelines are the Quran and Hadith. The Prophet is a figure that can be used as the example in organizing education in all things including the formation of character. As it is very clearly stated in the Qur'an "There has certainly been for you in the Messenger of Allah an excellent pattern for anyone whose hope is in Allah and the Last Day and [who] remembers Allah often" (QS. Al-Ahzab: 21). The expected output, after students graduated from the school he will be a figure of courteous, ethical, as well as its presence in the environment of society can bring benefit for others. But that hope is different from reality when the students in the school through the process of course still frequently truant, but everyone must understand that education is an investment in the world to live their lives toward the hereafter.

Because of the increasing phenomenon of truant students done, then to deal with the behavior of truancy in the effort to build character in accordance with Islamic education, counselors provide group counseling using the technique of cognitive restructuring. Cognitive restructuring process an individual has implications for behavior change. Members of the group often express the mind of oneself and negative self-talk when they are in stress. There are some disruptive behavior can be solved by using cognitive restructuring technique. Based on the results of the study Erfantinni, Purwanto, \& Japar (2016) cognitive behavior therapy group counseling with cognitive restructuring technique was effective for reducing academic 
procrastination. The cognitive restructuring technique were suitable for both male and female students. Similar study by Fadil, Sunawan, \& Awalya (2019) also stated in the results of his study that Cognitive Restructuring technique was effective to reduce students' internet addiction. Cognitive restructuring is a process of identifying and evaluating one's cognition, understanding the impact of negative thoughts and behavior, then learn to replace these with a more realistic mind, appropriate, and adaptive. Members are expected to identify the selfcognition and self-talk to monitor themselves. Cognitive restructuring is the most basic component of cognitive-behavioral procedures (Cormier, Nurius, \& Osborn, 2008). Likewise, with Corey (2013) cognitive restructuring is a process of identifying and evaluating one's cognition, understanding the impact of the behavior of certain negative thoughts, and learn to replace cognitions with more realistic, right, and the Adaptive mind.

There are a lot of studies have investigate the impact of cognitive restructuring within counseling, but none of them have determine the effectiveness of cognitive restructuring to reduce truancy particularly on the purpose of character building. Therefore, the aim of this study is to determine the effectiveness of cognitive restructuring to reduce truancy.

\section{METHODS}

This study uses a design Randomized Pretest-Posttest Control Group Design. This design is an extension of the single - group pretest-posttest design in two ways, plus a control group and subjects chosen at random in each group (Purwanto, 2013). The design can be seen in Figure 1.

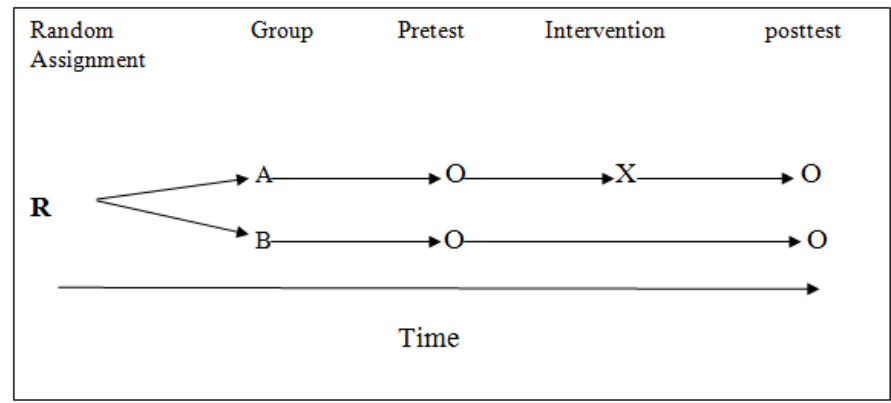

Figure 1. Randomized Pretest-Posttest Control Group Design

Population in this study are all of the students at Surabaya Pharmacy School classes X, XI, XII. Sample selection based on recommendations from the teacher and attendance list. And then they are given a truant behavior scale which consists of 35 items with the lowest validity value 0,411 and the highest validity value 0,862 and the reliability are 0,961 . After given the truant behavior scale, that it is known the student truant level. Then formed counseling groups based on the highest score. One group consist of 6 students as experimental group and control group that also consist of 6 students. The experiment group was given intervention cognitive restructuring technique. The control group was given counseling treatment conventionally. After treatment, we compare between experimental group and control group. Data on this study was collected quantitatively, using technique of data analysis non-parametric T-Test to find out how behavior truancy are reduced before and after treatment.

\section{RESULTS AND DISCUSSION}

The results of testing cognitive restructuring technique in reducing truancy behavior showed a significance decrease of the truancy. The results of data calculation before and after 
the intervention showed that the technique of cognitive restructuring group of experimental and control groups are presented in Table 1.

\begin{tabular}{ccccccc}
\hline \multirow{2}{*}{ Measurement } & \multicolumn{2}{c}{ Pretest } & \multicolumn{2}{c}{ Posttest } & \multirow{2}{*}{ t } & \multirow{2}{*}{ p } \\
\cline { 2 - 5 } & $\mathbf{M}$ & SD & M & SD & & $<0.05$ \\
Experiment $(\mathrm{N}=6)$ & 98.5 & 14.19 & 68.33 & 10.80 & 6.664 & $<0.05$ \\
Control $(\mathrm{N}=6)$ & 105.66 & 17.65 & 103.33 & 16.31 & 1.453 & $>0.05$ \\
\hline
\end{tabular}

Table 1. Results of a Pretest and Posttest Data

Based on the data presented in Table 1, can be seen some difference between pretest and posttest score, posttest scores were lower than the mean pretest score. Experimental group experienced a lot of decline in truancy behavior after the intervention $(t=6.664,<0.05)$. In the other hand, the control group visible changes score between pretest and posttest results, posttest score lower than the mean pretest score so control group experienced a change in truancy after the intervention, but it much less than the experiment group $(\mathrm{t}=1.453,>0.05)$.

The significantly decrease of truancy is mostly due to the group leader able to change the negative thought into positive thought. As stated by Chandra, Wibowo, \& Sunawan (2019) cognitive-restructuring directs the counselee to avoid negative thought and seeds positive thought instead. In other words replacing the wrong perceptions or cognitions into more self-enhancing (Cormier \& Hackney, 2015).

The results of the study indicate that cognitive restructuring is effective in reducing truant match with the results of the study Erfantinni et al., (2016) which states that cognitive restructuring is effective in reducing academic procrastination. Similar findings by Fadil et al., (2019) according to the results of his study Cognitive Restructuring and Self-management technique were effective to reduce students' internet addiction. Based on the results of the study, it was knowing reliability from cognitive restructuring and found new alternatives to reduce truant behavior in an effort to build student character. This study provides benefits for school counselors to be able to apply cognitive restructuring to reduce truancy behavior.

Despite of the results of this study, authors have found some shortcomings. This study has a wide purpose to build the character of the student, but only limited to one variable. The other limitations of this study only focus on the cognitive area, even though there are so many factors that play a role in the truancy of students. in this study, the target of behavior is limited just truancy, therefore the next authors can further extend the target behavior (non-adaptive behavior) in order to get better results and to conduct a study with more self-character variables.

In the other hand, The effectiveness of the counseling of the cognitive restructuring technique contributes to add new knowledge about the concepts and practices of guidance and counseling, which can be used as a reference by authors in the future. This study is also expected to be able to be a stepping stone to complete various studies that have been done before. This study also provided the school counselors and guidance and counseling teachers a new alternative to build student character, particularly in reducing student truancy. The headmasters of school or the person in charge of the educational sector would have more method to improve the character of the student.

\section{CONCLUSIONS}

The cognitive restructuring technique in counseling is effective to reduce students' truant behavior of Surabaya Pharmacy School. Cognitive restructuring technique also help individuals to find the negative perceptions that adverse and replace it with positive perceptions that more effective for the individual. 


\section{ACKNOWLEDGMENTS}

The authors sincere their appreciations to the headmaster of Surabaya pharmacy school, students which involved in the control or experiment group, and everyone who has contribute their time, thought, and energy to help the author finish their research.

\section{AUTHOR CONTRIBUTION STATEMENTS}

The authors had participated in the research and approved the final version of the manuscript.

\section{REFERENCES}

Agung, L. S. (2016). The Role of Social Studies and History Learning in Junior High School in Strengthening the Students Character. Paramita: Historical Studies Journal, 25(2), 238-246. https://doi.org/10.15294/paramita.v25i2.5134

Claes, E., Hooghe, M., \& Reeskens, T. (2009). Truancy as a contextual and school-related problem: a comparative multilevel analysis of country and school characteristics on civic knowledge among 14 year olds. Educational Studies, 35(2), 123-142. https://doi.org/10.1080/03055690802470258

Chandra, E. K., Wibowo, M. E., \& Sunawan, S. (2019). Cognitive Behaviour Group Counseling with Self-Instruction and Cognitive Restructuring Technique to Improve Students' Self-Confidence. Islamic Guidance and Counseling Journal, 2(1), 11-17. https://doi.org/10.25217/igcj.v2i1.305

Corey, G. (2013). Theory and practice of counseling and psychotherapy. Belmont, CA: Cengage Learning. Retrieved from Google Scholar

Cormier, S., \& Hackney, H. L. (2015). Counseling Strategies and Interventions for Professional Helpers. Pearson Higher Ed. Retrieved from Google Scholar

Cormier, S., Nurius, P. S., \& Osborn, C. J. (2008). Interviewing and Change Strategies for Helpers: Fundamental Skills and Cognitive Behavioral Interventions, 6th. Retrieved from Google Scholar

Erfantinni, I. H., Purwanto, E., \& Japar, M. (2016). Konseling Kelompok Cognitive-Behavior Therapy dengan Teknik Cognitive Restructuring untuk Mereduksi Prokrastinasi Akademik. Jurnal Bimbingan Konseling, 5(2), 119-125. Retrieved from Google Scholar

Fadil, M., Sunawan, S., \& Awalya, A. (2019). The Effectiveness of Group Counselling with Cognitive Restructuring and Self-Management Technique to Reduce Internet Addiction. Jurnal Bimbingan Konseling, 8(2), 134-139. Retrieved from Google Scholar

Martin, G., \& Pear, J. J. (2015). Behavior modification: What it is and how to do it. Psychology Press. Retrieved from Google Scholar

Mccray, E. D. (2006). It's 10 a.m.: Do You Know Where Your Children Are?: The Persisting Issue of School Truancy. Intervention in School and Clinic, 42(1), 30-33. https://doi.org/10.1177/10534512060420010501

McKinney, S. (2013). Truancy: A Research Brief. Status Offense Reform Center. Retrieved from Google Scholar

Morrison, B. (2013). Restorative justice in schools. In New directions in restorative justice (pp. 50-76). https://doi.org/10.4324/9781843926429-9 
Purwanto, E. (2013). Metode Penelitian Kuantitatif. Semarang: Fakultas Ilmu Pendidikan Universitas Negeri Semarang.

Ramberg, J., Låftman, S. B., Fransson, E., \& Modin, B. (2019). School effectiveness and truancy: a multilevel study of upper secondary schools in Stockholm. International Journal of Adolescence and Youth, 24(2), 185-198. https://doi.org/10.1080/02673843.2018.1503085

Sheppard, B., \& Dibbon, D. (2011). Improving the Capacity of School System Leaders and Teachers to Design Productive Learning Environments. Leadership and Policy in Schools, 10(2), 125-144. https://doi.org/10.1080/15700763.2010.502610

Swansea, K. R. (2010). Finding Strategic Solutions to Reduce Truancy. Research in Education, 84(1), 1-18. https://doi.org/10.7227/RIE.84.1 